\author{
ACTA MYCOLOGICA \\ Vol. 43 (1): 13-19 \\ 2008
}

\title{
Studies on toxicity of selected Oomycetes
}

\author{
KINGA MAZURKIEWICZ-ZAPAŁOWICZ ${ }^{1}$, ARTUR SILICKI ${ }^{1}$, JAN GRAJEWSKI ${ }^{2}$ \\ and AGNIESZKA WOŹNIAK ${ }^{2}$
}

\begin{abstract}
${ }^{1}$ Department of Hydrobiology, Faculty of Food Technology and Fisheries, University of Agriculture in Szczecin, K. Królewicza 4, PL-71-450 Szczecin, zapalowicz@fish.ar.szczecin.pl ${ }^{2}$ Institute of Biology and Environmental Protection, Kazimierz Wielki University in Bydgoszcz Chodkiewicza 30, PL-85-064 Bydgoszcz
\end{abstract}

Mazurkiewicz-Zapałowicz K., Silicki A., Grajewski J., Woźniak A.: Studies on toxicity of selected Oomycetes. Acta Mycol. 43 (1): 13-19, 2008.

The MTT test is used to determine the cytotoxicity of species: Achlya americana, A. caroliniana, Leptomitus lacteus, Saprolegnia ferax and S. lapponica, which occurred in Lake Sitno in the Drawieński National Park (W Poland). It was stated that among five examined species of zoosporic fungi only one of them $A$. caroliniana, does not show cytotoxic effect. Low and mean toxicity of other tested water FLO, however, combined with the large-scale character of their appearance shows, that they can create serious threat for the spawn, fry, fish as well as the other organisms (including invertebrates) existing in water.

Key words: Oomycetes, toxicity, aquatic fungi, MTT-test

\section{INTRODUCTION}

Water fungi play a crucial part in the biological decomposition of dead plant and animal remains - detritus, in water reservoirs. The above activity is a significant biodegrading potential which makes it possible and guarantees the correct run of selfpurifying process of waters. Enzymes of water fungi, that hydrolyze chitin, keratin, lignin, or cellulose, make it possible to release carbon, as well as a number of inorganic compounds. On one hand, substances which result from the above processes are used by fungi to build their own hyphae, on the other hand, they guarantee the recycling of elements in environment. The above saprotrophic mode of feeding is not a permanent property, because fungi modify their metabolism and switch to the parasitic form of feeding under influence of various factors present in the environment. The above statement applies also to water fungi, they can be either zoopathogenic, or phytopathogenic.

Research on water fungi present on muscular tissues and on fish spawn is so far very fragmentary in Poland. It concerns only the cognition of biodiversity of zoosporic fungi that are present with development and growth of fish (Czeczuga 1996; 
Czeczuga, Kiziewicz 1999; Czeczuga, Muszyńska 1999; Kiziewicz 2004). There is a lack of data concerning pathogenic effect, and eventual toxicity, of water fungi on living organisms. The problem concerns directly the wholesomeness of fish spawn, and thus it is decisive for fish-cultures. Hence, the above research is justified not only for cognitive, but also for practical reasons. Water fungus-like organisms (FLO) species common in reservoirs: Achlya americana Hamphrey, A. caroliniana Coker, Leptomitus lacteus Agardh, Saprolegnia ferax (Gruith.) Thuret and S. lapponica Gäum. were chosen for the research. In relation to zoosporic fungi, the above research has been carried out for the first time. On the basis of cytotoxicity test, potential threat for ichtyofauna, related to production of mycotoxins by the fungi, has been estimated.

\section{MATERIALS AND METHODS}

Research material, zoosporous fungi, was obtained from the Sitno Lake (Drawieński National Park), in the spring of 2005. Sitno Lake is a shallow $(7 \mathrm{~m})$, polymyctic reservoir of eurotrophic character. Fecundity of waters in the above lake is enriched with biogenic substances from the cultivated land surrounding the reservoir, as well as from the river Płociczna flowing through the lake (Piotrowicz et al. 1998). Dominant fish in the stock are roach (Rutilus rutilus), perch (Perca fluviatilis), alburn (Alburnus alburnus), and bream (Abramis brama). Concurrent species in the stock of fish are: rudd (Scardinius erythrophthalmus), eel (Anguilla anguilla), pike (Esox lucius), ruff (Gymnocephalus cernuus), fish of the family Cyprynidae white bream (Blicca bjoerkna), tench (Tinca tinca), bitterling (Rhodeus sericeus), lake bulltrout (Salmo trutta m. lacustris) (www.dpn.pl).

Zoosporic fungi tribes were obtained from the sub-superficial zone and from the ground zone, and they were cultivated in the laboratory according to the method of bait (Batko 1975). Mycelia, that successively developed on the baits, were observed under microscope and determined according to the taxonomic test in keys: Skirgiełło (1954); Batko (1975) and Riethmüller (2000). For toxicity research, tribes of most common species were used: Achlya americana, A. caroliniana, Saprolegnia ferax, S. lapponica and Leptomitus lacteus.

Achlya americana Hamphrey. Species forms a white, rigid turf, with width of ca 2 $\mathrm{cm}$. The turf consists of strong hyphae with dimensions: 40-100-(150) $\mu \mathrm{m}$ distributed radially. Zoosporangia form at the ends of hyphae and they are not much wider from hyphae, cylindrical, spindle-shaped, and they reach the length of 127-350-(600) $\mu \mathrm{m}$ (Fig. 1A). Zoospore, with diameters of $11 \mu \mathrm{m}$, descend through openings in the sporangium, or sometimes, they germinate while still in the sporangium. Oogonia are spherical, they are placed on short stalks, gathered in clusters with diameters of 3070-(150) $\mu \mathrm{m}$ (Fig. 1B). Numerous spores appear often in smooth walls of oogonium. Oospores are spherical, they reach the diameter of $20-25 \mu \mathrm{m}$ and they usually appear in the number of 3-18 (sometimes up to 40).

A. caroliniana Coker. Hyphae of this FLO are 25-50 $\mu \mathrm{m}$ thick, and zoosporangia are of dimensions: $259-418 \times 32 \mu \mathrm{m}$. Zoospore reach the size of 10-11 $\mu \mathrm{m}$. The FLO forms spherical oogonia, which are gathered in clusters. The oogonium has a smooth membrane, often without pores; sometimes, a papilla is formed. There is a lack of 
antheridium. Oospores are formed in the number of 1-2 (rarely in the number of 3-4), and they reach the diameter of 20-25 $\mu \mathrm{m}$.

Saprolegnia ferax (Gruith.) Thuret. Fungus forms a white, compact, spherical, and dense mycelium. Turf of this mycelium reaches the width of $1-2 \mathrm{~cm}$, and its hyphae are up to 25-75 $\mu \mathrm{m}$ thick (Fig.1C). Zoosporangia of this species show a big diversity in shape and size. The size of floating sporangia varies in the range of $40-500 \mu \mathrm{m}$, while the zoospores have diameters of $10 \mu \mathrm{m}$ (Fig.1D). Oogonia form on the main hyphae, and on the side hyphae. They are spherical, pear-shaped, or oval-shaped, with dimensions: $75 \times 38-92 \mu \mathrm{m}$. There also appear numerous spores (5-40), with diameters of $24-27 \mu \mathrm{m}$.

S. lapponica Gäum. Fungus forms turf, hyphae, and zoosporangia which resemble the sporangia of $S$. ferax. Oogonia are most often sitting, or they are placed on short stalks (Fig.1E). Diameter of oogonium is of $45-75-100 \mu \mathrm{m}$, pores are present on its surface. There is a lack of antheridium. In comparison with $S$. ferax, oospores of $S$. lapponica are smaller. Their diameters are of $20-22 \mu \mathrm{m}$, and they are formed in a smaller number (4-12).

Leptomitus lacteus Agardh. FLO forms a white turf which winds round various objects that are present in water. Sometimes, mycelium turns yellow in reaction to bacteria. Hyphae are characterized with cylindrical narrowings, they have dimensions of: $100-400 \times 10-20 \mu \mathrm{m}$. Narrowed hyphae form separate segments, and each segment functions as a zoosporangium (Fig. 1F).

Isolates of the above species were material for further research. Multiple agar medium was applied in the research. It consisted of agar maize flour $(8.5 \mathrm{~g})$; peptone $(0.5$ $\mathrm{g})$; yeasts extract $(0.5 \mathrm{~g})$; glucose $(0.5 \mathrm{~g})$; starch flour $(2.5 \mathrm{~g})$; distilled water $(500 \mathrm{ml})$. The medium was sterilized 3 times in Koch apparatus. Then, it was poured on Petri plates with diameter of $\varnothing 90 \mathrm{~mm}$, and after the pure cultures of tested fungi were inoculated, they were incubated in the room temperature within 3 weeks. Control media were treated in the same way, they did not contain the inoculum of mycelium.

FLO cultures were used in research for toxicity, with application of tetrazole salt MTT (3[4,5-dimetyltiazol-2-yl]-2,5-difenyltetrazlium bromide, Sigma Aldrich), and with application of cells of kidneys obtained from swine (SK), after they were extracted with chloroform. The basic idea of cytotoxicity MTT test is to transform the yellow-coloured tetrazole salts into violet-coloured, insoluble in water, crystals of formazan. The process occurs exclusively in mitochondria of live and metabolically active cells. The process does not occur in cells which were damaged by toxins. If the cell was damaged, or ravaged, as an effect of a toxin, the process of tetrazole salts reduction is slowed down, or inhibited. As a result, tetrazole salts remain yellowcoloured. Thus, the test provides the information about biological results, that is, cytotoxicity (Hanelt et al. 1994). It does not provide the information about the kind of appearing mycotoxins. Change of colour intensity is the indicator of toxicity degree, and it is photometrically determined with the wavelength of $510 \mathrm{~nm}$.

Cytotoxicity MTT test was carried out in microtitrating plates. Controls and sample cultures of zoosporous fungi used for cytotoxicity research were diluted in the MEM medium (Minimum Essential Medium Eagle, Sigma Aldrich), which contained $1.7 \%$ of ethanol $(\mathrm{POCH})$, and $0.3 \%$ DMSO (Merck) in the proportion: 1:2. Successive dilutions were placed in MTT test plate with SK cells diluted in the 
medium with ethanol and DMSO, and with addition of $10 \%$ FCS (fetal calf serum, Sigma Aldrich). The plates were incubated in temperature of $37^{\circ} \mathrm{C}$ in time of $48 \mathrm{~h}$. Then, MTT dilution in PBS (Merck) was added and there occurred further incubation, in the time of $4 \mathrm{~h}$. After the liquid was removed, DMSO was added as a dissolvent for formazan crystals. After 5 min of shaking in shaker (Titramax 101, Heidolph), toxicity was determined by means of microtitrating plates indicator (Miktotek Laborsysteme, ASYS Hitech GmbH), with the wavelength of $510 \mathrm{~nm}$.

According to the successive grades of dilution, the grade of cytotoxicity - IC50, that is the concentration of a sample, where the cell proliferation was inhibited to $50 \%$ in relation to control cells, was determined.

\section{RESULTS AND DISCUSSION}

As a result of research carried out by means of cytotoxicity MTT test, it was stated that from five species of zoosporic fungi under research, only one species, $A$. caroliniana, does not show cytotoxic effect. Further three species: Saprolegnia ferax, S. lapponica, Achlya americana, show cytotoxicity on the level of IC $5015.63 \mathrm{~cm}^{2} / \mathrm{ml}$. According to assumed toxicity estimation scale (Tab.1; Fig. 2) (Hanelt et al. 1994; Twarużek 2005), the above value is only of low grade of cytotoxicity.

On the other hand, Leptomitus lacteus showed to be of medium-toxicity (Tab. 1), with the IC 50 cytotoxicity level of $4.91 \mathrm{~cm}^{2} / \mathrm{ml}$.

Carried out research showed that MTT test, used so far in estimation of contamination of food and interiors with toxic substances (Twarużek 2005), as well as in estimation of toxicity of some medicine (Kołodziej et al. 2005), proved to be sensitive enough, that it can be advantageously used to test cytotoxicity of water microorganisms. The above fact proves versatility of MTT test in research on cytotoxicity. Due to the above fact, cytotoxic properties of some species of zoosporous fungi were proved for the first time, and thus the knowledge concerning the role of Hydromycetes in water ecosystems has been enriched significantly. Low toxicity of tested water FLO, however in comparison with large-scale character of their appearance shows, that they can relevantly menace the spawn, fry, fish, as well as the other organisms existing in water.

Table 1

Results of research on selected Oomycetes by means of MTT cytotoxicity test

\begin{tabular}{|l|c|c|}
\hline \multicolumn{1}{|c|}{ Kind of trial } & $\begin{array}{c}\text { IC 50 } \\
{\left[\mathrm{cm}^{2} / \mathrm{ml}\right]}\end{array}$ & $\begin{array}{c}\text { Estimation } \\
\text { of cytotoxicity* }\end{array}$ \\
\hline Control medium & $>31.25$ & $(-)$ \\
\hline Achlya caroliniana & 39.250 & $(-)$ \\
\hline Achlya americana & 15.625 & $(+)$ \\
\hline Saprolegnia lapponica & 15.625 & $(+)$ \\
\hline Saprolegnia ferax & 15.625 & $(+)$ \\
\hline Leptomitus lacteus & 4.910 & $(++)$ \\
\hline
\end{tabular}

Abbreviations: *estimation of cytotoxicity: (-) lack of cytotoxicity, $(+)$ low cytotoxicity, $(++)$ medium cytotoxicity, $(+++)$ high cytotoxicity. 


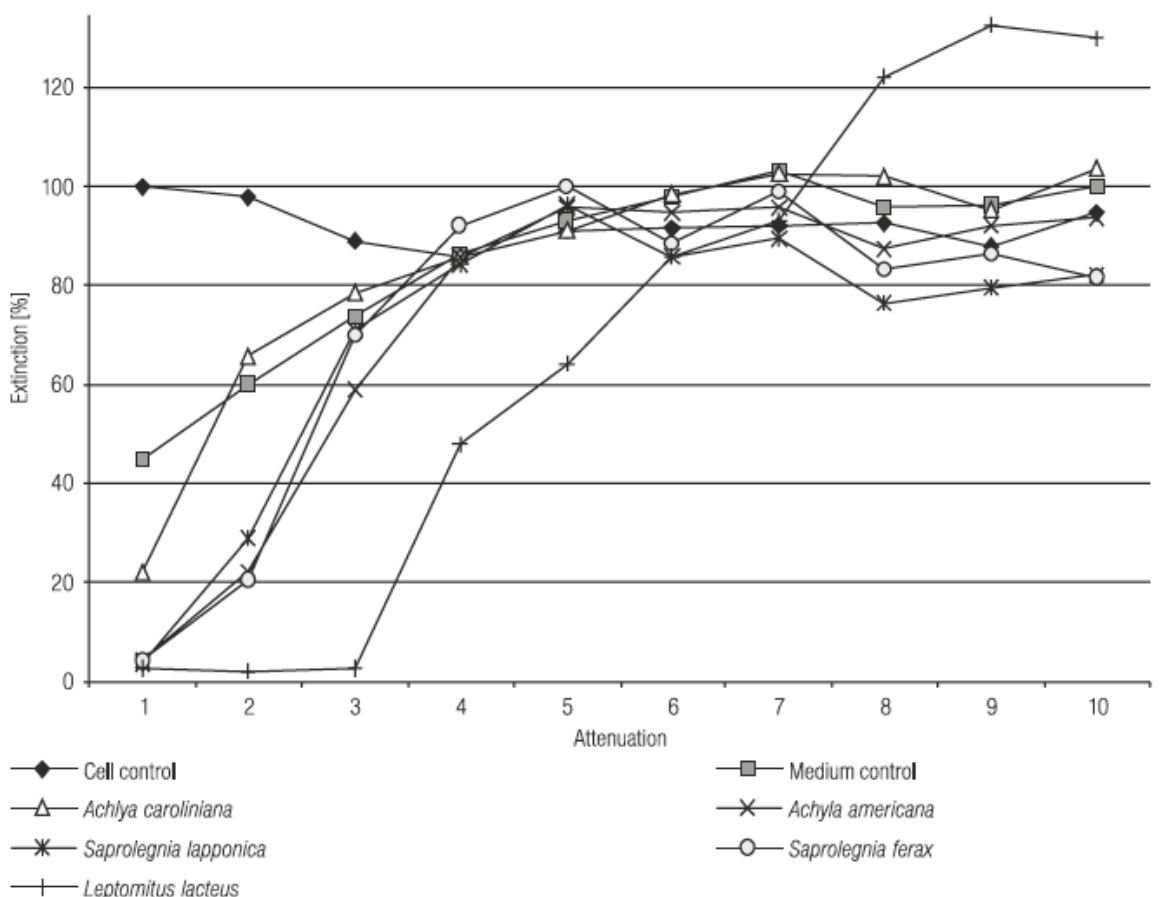

Fig. 2. Extinction graph from Elisa reader.

So far obtained information concerning parasitism of S. ferax on salmon (Salmo salar) (Czeczuga et al. 2002 after Stirling 1880), in the context of stated cytotoxicity mentioned above, make it possible to assume that, in conditions advantageous for infections, the above fungus contributes in mass death of fish. All the more so as with participation of $S$. parasitica and species of Achlya type, S. ferax is observed commonly on a number of fish species (Dudka et al. 1989), and on spawn (Pickering, Willoughby 1982). Czeczuga and Kiziewicz (1999), suggest that in many cases, the above FLO could infect healthy spawn and thus provoke its death. A similar assumption, justified with research results, could refer to FLO of the Achlya genus. Achlya is known to be isolated from fish spawn (Khulbe, Sati 1981; Czeczuga, Muszyńska 1997; Czeczuga et al. 2002). In relation to cytotoxicity of Achlya, its zoopathogenic role can be suggested. Czeczuga and Muszyńska (1999) and Kiziewicz (2004), also inform about the above specialization of $S$. ferax, present together with $A$. debaryana and $A$. klebsiana in muscular tissues of wounded fresh-water fish. However, they do not present proved research on cytotoxicity.

Worsening environmental conditions, as a result of influx of biogenic elements to waters, can speed up fungous infections. Enhanced contents of nitrogen compounds caused parasitizing the species of guppy (Poecilia reticulata) and swordtail (Xiphophorus helleri), cultures grown in laboratory, by FLO from the Saprolegniaceae family (Nolar-Tintigner 1978; Carballo, Muñoz 1991).

Hence, zoosporic fungi can significantly disturb the fish culture, even if cytotoxicity in eutrofic reservoirs is low, or medium. The Sitno Lake, in Drawienski National Park, shows a high level of eutrophication (Piotrowicz et al. 1998). Mass 
development of cytotoxic Oomycetes in this lake can proceed to particularly threatening results. The above statement is confirmed by occurrence of Leptomitus lacteus unit of classification in the Sitno Lake. The species is used for bio-indication of purity of waters. L. lacteus is defined as a "sewage fungus" (Batko 1975), and it occurs in strongly contaminated waters, mostly in municipal sewage. Stimulation of $L$. lacteus is also observed with enhanced presence of biogenes (Czeczuga, Woronowicz 1991-1992). The FLO was found on Petromyzon marinus (Lemon 1954; Czeczuga et al. 2002), it parasitized spawn of crucian carp (Carassius carassius), altogether with S. ferax and the other species of Achlya and Saprolegnia genera (Czeczuga, Kiziewicz 1999). Medium cytotoxicity grade of L. lacteus, stated in research, causes that its occurrence can threaten the spawn and the fry. Results of the above fact are definitely negative for home ichtyofauna. On the other hand, they can be a significant factor limiting extraneous fauna of the gobid family of fishes, that are undesirable in Polish reservoirs: Neogobius fluviatilis, N. gymnotrachelus, Perccottus glenii, Pseudorasbora parva (Czeczuga, Muszyńska 1997).

Stated cytotoxic properties of Oomycetes under research can also additionally contribute in perturbation of homeostasis in water reservoirs, by the possibility to parasitize on water invertebrates, on omnivorous organisms, e.g. crayfish: Astacus astacus, A. leptodactylus, Orconectes limosus, and Pacifastacus leniusculus (Czeczuga et al. 1998), Cambarus affinis (Czeczuga 1994), as well as on fresh-water filtratorsshellfish (Czeczuga 2000), or parasitc leech (Hirudinea) (Czeczuga et al. 2003).

Occurrence of zoosporic fungi with cytotoxic properties in various levels of trophic chain causes that their ecological part acquires significance.

However, not all zoosporic fungi isolated from spawn and fish show cytotoxic properties, e.g. A. caroliniana, species found on fish and other water organisms (Kiziewicz 2004).

Discussed initial results of research on cytotoxicity of Hydromycetes advocate for further research and broadening its scope. It is also necessary to investigate the chemical character of compounds produced by zoosporic fungi, while the above compounds indicate cytotoxic properties of zoosporic fungi.

Acknowledgements. The authors of the paper thank the Management and the Staff of Drawieński National Park (Poland) for the help in collecting research materials.

\section{REFERENCES}

Batko A. 1975. Zarys hydromikologii. PWN, Warszawa.

Carballo M., Muñoz M. J. 1991. Effect of sublethal concentrations of four chemical on susceptibility of juvenile rainbow trout (Oncorhynchus mykiss) to Saprolegniosis. Appl. Environ. Microbiol. 57 (6): 1813-1816.

Czeczuga B. 1994. Aquatic fungi of twelve Augustów Lakes with reference to the chemistry of the environment. Acta Mycol. 29 (2): 217-227.

Czeczuga B. 1996. Species of Pythium isolated from eggs of fresh-water fish. Acta Mycol. 3 (2): 151-161.

Czeczuga B. 2000. Zoosporic fungi growing on freshwater Molluscs. Pol. J. Environ. Stud. 9 (3): 151156.

Czeczuga B., Kiziewicz B. 1999. Zoosporic fungi growing on the eggs of Carassius carassius (L.) in oligoand eutrophic water. Pol. J. Environ. Stud. 8 (2): 63-66.

Czeczuga B., Kiziewicz B., Danilkiewicz Z. 2002. Zoosporic fungi growing on the specimens of certain fish species recently introduced to Polish waters. Acta Ichthyol. et Piscat. 32 (2): 117-125.

Czeczuga B., Kiziewicz B., Godlewska A. 2003. Zoosporic fungi growing on Leeches (Hirudinea). Pol. J. Environ. Stud. 12 (3): 361-369. 
Czeczuga B., Muszyńska E. 1997. Aquatic fungi growing on the eggs of Polish cobitis fish species. Acta Hydrobiol. 39 (3/4): 67-75.

Czeczuga B., Muszyńska E. 1999. Aquatic fungi growing on percid fish eggs (Percidae) in Poland. Pol. J. Environ. Stud. 8 (1): 31-34.

Czeczuga B., Muszyńska E., Godlewska A. 1998. Aquatic fungi on certain species of crayfish in water from different water bodies. Pol. J. Environ. Stud. 7 (2): 75-82.

Czeczuga B., Woronowicz L. 1991-1992. Studies on aquatic fungi. XXI. The Lake Mamry complex. Acta Mycol. 27 (1): 93-103.

Dudka I. A., Isayeva N. M., Davydow O. N. 1989. Saprolegniewye griby-wozbuditeli mikozow ryb (Saprolegniaceae indicating fish mycosis). Mycol. Phytopathol. 23: 488-498.

Hanelt M., Gareis M., Kollarczik B. 1994. Cytotoxicity of mycotoxins evaluated by the MTT-cell culture assay. Mycopathologia 128: 167-174.

Khulbe R. D., Sati S. C. 1981. Studies of parasitic water molds of Kumaum Himalaya: host range of Achlya americana Hamphrey of certain temperature fish. Mycosen 24: 177-180.

Kiziewicz B. 2004. Aquatic fungi growing on the muscle of vendace (Coregonus albula L.), alpine bullhead (Cottus poecilopus H.) and lake trout (Salmo trutta lacustris L.) from Lake Hańcza (NE Poland). Zool. Pol. 49 (1/4): 85-95.

Kołodziej B., Kuryło-Rafińska B., Styczyński J., Kubika M., Dębski R. 2005. Porównanie aktywności trzech preparatów L-asparginazy w ostrej białaczce limfoblastycznej i mieloblastycznej: badania cytotoksyczności i indukcji apoptozy w liniach komórkowych. Współcz. Onkol. 9: 1-6.

Lemon R.E. 1954. Feeding mechanism of the sea lamprey and its effect on host fishes. Fish. Bull. Fish Wildl. Serv. U.S. 56: 247-293.

Nolar-Tintigner R. N. 1978. Ability of zoospores versus oospores to cause saprolegniasis in fish. Acta Zool. Path. Antverp. 57:1-27.

Pickering A.D., Willoughby L.G. 1982. Microbial diseases of fish. (In:) R. J. Roberts (eds). Academic Press, London: 271-297.

Piotrowicz R., Klimaszczyk P., Kraska M. 1998. Wyniki badań fizyczno-chemicznych wód jezior i rzek Drawieńskiego Parku Narodowego na podstawie analiz z okresu cyrkulacji wiosennej i stagnacji letniej 1997 roku. Operat Ochrony Ekosystemów Wodnych Drawieńskiego Parku Narodowego (msc).

Riethmüller A. 2000. Morphologie, Ökologie und Phylogenie aquatischer Oomyceten. Bibliotheca Mycologica, Berlin-Stuttgart.

Sitno, access in world wide web: www.dpn.pl/content.php? $\mathrm{mod}=$ sub\&cms_id $=2 \mathrm{cms} \_s$ _id $=8 \&$ lang $=$ pl [access 04. 05. 2006].

Skirgiełło A. 1954. Grzyby niższe. Pragrzyby i glonowce. Przewodnik morfologiczno-systematyczny z kluczami do oznaczania. PWN Warszawa.

Stirling A. B. 1880. Additional observations on fungus disease of salmon and rother fish. Proc. Roy. Soc. Edinburgh 10: 232-378.

Twarużek M. 2005. Wykorzystanie biologicznych testów (MTT, Premi ${ }^{\oplus}$ Test) w ocenie skażeń pomieszczeń mieszkalnych mikotoksynami grzybów pleśniowych. Rozprawa doktorska. Uniwersytet Kazimierza Wielkiego w Bydgoszczy (msc).

\section{Badania toksyczności wybranych Oomycetes}

Streszczenie

Test MTT zastosowanao do badań cytotoksyczności szczepów: Achlya americana, A. caroliniana, Leptomitus lacteus, Saprolegnia ferax i S. lapponica pozyskanych z Jeziora Sitno w Drawieńskim Parku Narodowym. Stwierdzono, że spośród pięciu wymienionych grzybów zoosporowych tylko $A$. caroliniana nie wykazuje działania cytotoksycznego. Udowodniona niska i średnia toksyczność pozostałych gatunków OGP, w zestawieniu $\mathrm{z}$ ich masowym występowaniem w środowisku wodnym, wskazuje, że mogą one stanowić istotne zagrożenie dla ikry, narybku i ryb oraz innych organizmów, w tym także bezkręgowców, żyjących w wodzie. 

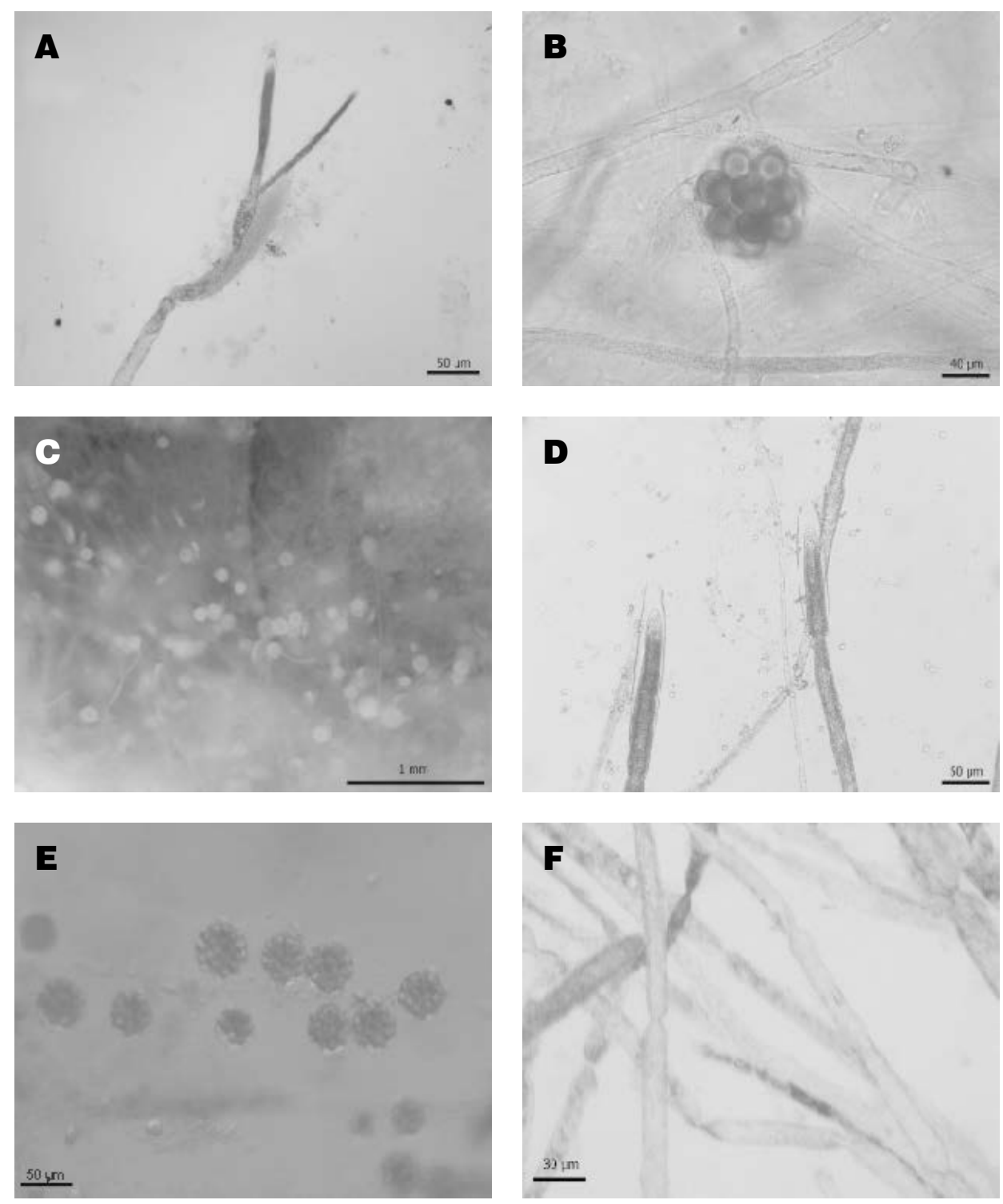

Fig. 1. Some toxic Oomycetes: A - sporangium of Achlya americana; B - oogonium of A. americana; C - Saprolegnia ferax growing on spawn of fish; D - sporangium of S. ferax, E - oogonium of S. lapponica; F - hyphae of Leptomitus lacteus. 